\title{
ZS Research Square \\ Prevalence of malnutrition in School aged children, Kassala State, Sudan
}

Fatima Abbas Khalid Khalid

Kassala University

Muataz Mohamed Eldirdery Eldirdery

Institute of tropical Medicine,Khartoum,Sudan

Mamoun El-obeid ElGasim ElGasim

Kassala University

Malak Abd Elmajid Elhaj Elhaj

Kassala University

Mohamed Abd Alrazik Desogi Desogi ( $\sim$ abuomer2015.mz@gmail.com )

Kassala University

Maowia Mohamed Mukhtar Mukhtar

Research Institute of Bioscience,Ibn Sina university Khartoum Sudan

\section{Research Article}

Keywords: malnutrition, school children, Kassala, Sudan

Posted Date: October 13th, 2021

DOI: https://doi.org/10.21203/rs.3.rs-939475/v1

License: (c) (i) This work is licensed under a Creative Commons Attribution 4.0 International License.

Read Full License 


\section{Abstract}

Background : Childhood malnutrition is a major concern in developing countries due to high morbidity and mortality rate. To estimate the prevalence of malnutrition among school children, Kassala State, A cross-sectional study was conducted randomly among 2638 children. Height for age and body mass index for age $z$ scores were calculated using WHO Anthro Plus software as indicators of stunting and thinness respectively. A multinomial logistic regression model was used to determine the associated factors.

Results: The overall prevalence of stunted and thinness was $22.1 \%$ and $32.3 \%$ respectively. Stunting was significantly higher among children in age group $13-15$ years old (OR 3.788; 95\% Cl: 2.802- 5.123), boys (OR 1.394; 95\% Cl: 1.114-1.743) and children from rural areas (OR 2.406; 95\% Cl: 1.768-3.274). Likewise thinness was significantly higher among boys (OR 1.717; 95\% Cl: 1.436-2.052), Rural residence (OR 1.885; 95\% Cl: 1.487-2.389), child whose families depend on unsafe source of drinking water (OR 2.205; $95 \% \mathrm{Cl}: 1.484-3.276)$. Moreover, children who skipped meal during the school day or bring their food from their houses OR 2.744; 95\% Cl: 2.131- 3.532, 1.752(95\% Cl: 1.441-2.129) respectively). Maternal education and occupation, in addition to family size and child ordered had no effect on the prevalence of malnutrition.

Conclusions: In the present study, different forms of malnutrition was documented and affected by child age, gender, residence, source of drinking water. Therefore, more attention is needed to focus on nutrition status, improving the school environment, maternal education, and regular health assessment.

\section{Background}

Malnutrition is a public health problem, affects all people at different age in different regions, particularly South Asia and Africa [1]. Children and women are the most vulnerable groups due to their high nutritional requirements for growth and development [2]. Around half of deaths among children under 5 years of age are linked to under-nutrition [2]. Inadequate household income, food insecurity, poor access to basic sanitation and water services underlying the cause of malnutrition during an individual's childhood [3]. Malnutrition has negative impact on child health, cognition, education achievement and the quality of life $[4,5]$.

Stunting (chronic malnutrition) and wasting (acute malnutrition) are the most prevalent forms of malnutrition in children [6]. Globally, the prevalence rate of acute malnutrition was $14.1 \%$ [3] and the prevalence of stunting declined from $32.5 \%$ to $21.9 \%$ since $2000-2018$.

Sudan experiences of malnutrition render it among the highest countries in Middle East region. More than two million children in Sudan are already stunted [7]. The prevalence rate of under-five stunting and wasting is $38.2 \%$ and $16.8 \%$ respectively, which are greater than the average in developing countries [8]. Eastern Sudan States (Red Sea, Kassala and Gadarif) have high prevalence rate of malnutrition [3]. 
More than $50 \%$ of Sudan's population is children aged less than 18 years. However, most of the studies on malnutrition focus on children under-five age, leaving a gap on the nutrition status of children greater than five years old. Therefore, the present study is designed to estimate the prevalence of malnutrition among school children in 5-15 years age in Kassala State. Assessment of nutrition status of school children will help to identify children at risk so as to reduce the negative impact of malnutrition. Furthermore, it will provide a baseline data for school health.

\section{Methodology}

Study design and inclusion criteria

A school based cross sectional study was conducted at governmental elementary schools in three localities (Kassala, Western Reefi Kassala and Reefi Kassala) in Kassala State. The state was administratively classified into eleven localities. All of them are rural except Kassala and New Halfa. The study was conducted during the period from 2016 through 2018. All Children who attending during the period of data collection in the selected schools were enrolled in the study, whereas those who suffered from chronic diseases, or refused to participate were excluded from the study.

Sample size and sampling technique

The sample size was 3004. It was calculated according to the following estimation: the proportion of malnutrition in eastern Sudan $20.0 \%$ with marginal error $3 \%$ at $95 \%$ confidence interval $(d=0.03)$ and design effect of 4 . Ten percent of sample size was added to minimize errors arising from the likelihood of non compliance.

Multi-cluster random sampling technique was used for selection of pupils from 30 elementary schools from the three localities (randomly selected). The sample size was distributed among the selected schools proportionally based on student size in each school. Then, the number of participants required to be enrolled were allocated proportionally based on the number of students in each class and grade level.

Data collection

General information on age, sex, family size, number of meals per day and breakfast were collected in pretested questionnaire from children aged 5-15 years. Additionally, information about caregivers' education and occupation status were also collected. The questionnaire was administered by one or two teachers from each selected school. Then health was assessed by expertise medical practitioner followed by anthropometric measurements.

Anthropometric measurements

Child weight and height were measured following the standard methods with minimum clothing and without shoes. Weight was measured to the nearest 0.1 kilogram $(\mathrm{Kg})$ using an electronic weighing scale that is calibrated to the zero before taking every measurement. Height was measured to the nearest 
0.1 centimeters $(\mathrm{cm})$ in bare feet with participants standing upright against a mounted stadio-meter. Both measurements were recorded in the individual's questionnaire. According to WHO criteria and classification, child nutrition status was assessed [9].

Assessment of malnutrition

Anthro-Plus software (v. 3.2.2Jeneva, Switzerland) as WHO reference for 5-19 years school-age children and adolescents was used for assessment of child growth depending on z-score [10]. Child with Z score values of $<-2$ standard deviation for height for age and BMI for age were classified as stunted and thinness respectively. Child with z-score values $>+1$ and $>+2$ SD BMI-for-age were classified as overweight and obese respectively.

Statistical analysis

Statistical analysis was performed using the statistical package for Social Sciences for Windows IBM SPSS version 20 ((IBM Corp., Armonk, NY, USA)). Logistic regression was used to describe the significance of the association between the nutritional status outcome variables (stunting, thinness, and over-nutrition) and predictor variables (age, sex, residence, maternal educational status, family size, child order, source of drinking water and skipping of meal during school day). Odd ratio with $95 \%$ confidence intervals $(\mathrm{Cl})$ was used as a measure of association. Statistical significance was set at $\mathrm{P}<0.05$.

\section{Results}

\section{General characteristics}

Out of 3004 children, 366 (12.18\%) were excluded due to chronic illnesses or incomplete data leaving $2638(87.82 \%)$ with mean age $10.4 \pm 2.4$ years, and male to female ratio was 1:1.2. Most of them belonged to parents with low socioeconomic status; only $13.2 \%$ fathers had good level of education compared to $8.0 \%$ of mothers, their families size ranged from 2-17 with median 7 . They had different orders in their families; $42.2 \%$ of them had the first or second order in the family. The majority of children live in rural localities 1606 (60.9\%). They used different sources of water for drinking and daily supply. They received 2- 3 meals per day and 419 (15.88\%) of children did not eat anything during the day at school table (1).

Table (1): General characteristics of studied group 


\begin{tabular}{|c|c|c|}
\hline Variable & Frequency & Percent \\
\hline Sex: Male & 1437 & 54.5 \\
\hline Female & 1201 & 45.5 \\
\hline Age (years): 5-9 & 994 & 37.7 \\
\hline 10- 12 & 1063 & 40.3 \\
\hline $13-15$ & 581 & 22.0 \\
\hline Locality: Kassala & 1032 & 39.1 \\
\hline Reefi Kassala & 1023 & 38.8 \\
\hline Western Reefı Kassala & 583 & 22.1 \\
\hline \multicolumn{3}{|l|}{ Father education } \\
\hline Illiterate/ low level & 2290 & 86.8 \\
\hline Educated & 348 & 13.2 \\
\hline \multicolumn{3}{|l|}{ Mother education } \\
\hline Illiterate/ low level & 2427 & 92.0 \\
\hline Educated & 211 & 08 \\
\hline \multicolumn{3}{|l|}{ Father occupation } \\
\hline Employee/ skill worker & 650 & 24.6 \\
\hline Daily worker or had no work & 1988 & 75.4 \\
\hline Mother occupation : worker & 135 & 5.1 \\
\hline not worker & 2503 & 94.9 \\
\hline \multicolumn{3}{|l|}{ Source of drinking water } \\
\hline Tap/tanker & 2462 & 93.3 \\
\hline Unprotected open well & 176 & 6.7 \\
\hline Meals/ day: $\leq 2$ & 277 & 10.4 \\
\hline$>2$ & 2361 & 89.5 \\
\hline Breakfast : From house & 944 & 35.79 \\
\hline From school & 1275 & 48.33 \\
\hline Skipped & 419 & 15.88 \\
\hline
\end{tabular}


Nutrition status

The mean height, weight and BMI of studied groups were $133.98 \pm 13.15 \mathrm{~cm}$ and $27.76 \pm 8.7 \mathrm{Kg}$ and $15.13 \pm 2.72 \mathrm{Kg} / \mathrm{m} 2$ respectively. For boys, the overall anthropometric value as follows: mean height was $133.98 \pm 13.39 \mathrm{~cm}$, weight $27.44 \pm 8.51 \mathrm{Kg}$ and $\mathrm{BMl} 14.97 \pm 2.61 \mathrm{Kg} / \mathrm{m} 2$. The corresponding measurements for girls were $133.98 \pm 12.96 \mathrm{~cm}, 28.03 \pm 8.85 \mathrm{Kg}, 15.28 \pm 2.84 \mathrm{~kg} / \mathrm{m} 2$.

From the table (2) the proportion of well nourished children to malnourished approximately similar $(1: 1.02)$ and the proportion of acute malnutrition was twice the chronic malnutrition. The total stunted and thinness was $22.1 \%$ and $32.3 \%$ respectively.

Table (2): Nutrition status of studied group

\begin{tabular}{|ll|}
\hline Nutrition status & Frequency (\%) \\
\hline Normal height for age \& BMI for age & $1307(49.55)$ \\
\hline Chronic malnourished (stunted) & $324(12.28)$ \\
\hline Acute malnourished (Thinness) & $637(24.15)$ \\
\hline Overweight or obese & $111(4.21)$ \\
\hline Coexistence of stunted \& thinness & $215(8.15)$ \\
\hline Coexistence of stunted \& either overweight or obese & $44(1.67)$ \\
\hline
\end{tabular}

As shown in Fig.(1) the relatively high proportion of stunted was observed in the age group 13-15 years (39.4\%), among boys (26.7\%) and in rural localities (26.7\%\%). In the same way the proportion of acute malnutrition (thinness) was high in rural localities (38.5\%), among boys (38.4\%) and age group 13-15 yrs $(35.3 \%)$, where as the children in age $<13$ yrs has similar proportion of thinness and either over weight or obesity Fig (2).

Malnutrition and risk factors

Children in age of 10 years or greater were more likely to suffer from chronic malnutrition compared to those in age 5-9 years. The eldest children (13- $15 \mathrm{yrs}$ ) were more likely to suffer from stunted and severe stunted (OR 3.788(at 95\% Cl: 2.802- 5.123) and 8.570(at 95\% Cl: 5.368- 13.684). Likewise, the children in age 10-12 years were suffered from stunted and severe stunted. Boys were more likely to suffer from stunted OR 1.394(at 95\% Cl: 1.114-1.743). In the same way, children from rural localities were more likely to suffer from stunted and severe stunted OR 2.406(at 95\% Cl: 1.768-3.274) and OR 3.437(at 95\% Cl: 2.091-5.649) respectively. Unprotected open well as the source of drinking water increase the possibility 
of the development of chronic malnutrition, although it is insignificant (Stunted OR 1.065(0.664- 1.709) and severe stunted OR 1.047(0.534-2.054))

Although the prevalence of chronic malnutrition was statistically insignificant with the child ordered, family size, maternal education and occupation, and taking a meal during the school day, it was found that child ordered greater than third and belong to family size greater than 6 members were more likely to suffer from stunted. In the same way, maternal illiteracy will increase the possibility of stunting. Children who missed the meal during the school day were more likely to suffer from chronic malnutrition. Table (3)

Table (3): Relative risk ratios from multinomial logistic regression model for height for age for children in school age

As shown in table (4), The risk ratios for BMI for age indicate that the prevalence of low BMI for age was significantly associated with child sex, locality, source of drinking water and the meal took during the school day $(P<0.05)$. Contrary the child age, maternal education and occupation, family size and child ordered had no effect $(P>0.05)$ on the prevalence of malnutrition (thinness and either overweight or obese)

Boys were more likely to suffer from thinness OR $1.717(95 \% \mathrm{Cl}$ : 1.436- 2.052). In the same way children from rural localities OR $1.885(95 \% \mathrm{Cl}: 1.487-2.389)$. Unsafe source of drinking water was statistically affect the child nutrition status, as the thinness was more likely develop among children depends on unprotected open well for drinking and daily supply OR 2.205(at 95\% Cl:1.484- 3.276). In the same way the children who missed meal during the day at school or depend on meal brought from their houses were more likely to suffer from thinness OR $2.744(95 \% \mathrm{Cl}: 2.131-3.532)$ and $1.752(95 \% \mathrm{Cl}: 1.441-2.129)$. Although the age has no effect in the development of thinness and overweight, the children in age group 13- 15 years old were more likely to suffer from thinness OR $1.154(95 \% \mathrm{Cl}: 0.912-1.459)$.

Table (4): Relative risk ratios from multinomial logistic regression model for body mass index for age for children in school age

\section{Discussion}

The present study showed remarkable prevalence of malnutrition in different forms; stunted $(22.1 \%)$ and thinness (32.3\%). The prevalence was significantly associated with child age, sex, locality, and the source of drinking water. Boys, children in old age and those from rural localities were more likely to suffer from malnutrition, addition to those who depend on unsafe source of drinking water. Missing the meal during the day at school was effectively contributed in the prevalence of thinness.

The prevalence of malnutrition was recorded in low and middle income countries with variation within 


\begin{tabular}{|c|c|c|c|c|c|}
\hline \multirow[t]{2}{*}{ Variable } & \multirow[t]{2}{*}{ Category } & $\begin{array}{l}\text { Stunted Odd } \\
\text { ratio }\end{array}$ & \multirow[t]{2}{*}{$\begin{array}{l}\mathrm{P}- \\
\text { value }\end{array}$} & $\begin{array}{l}\text { Sever stunted } \\
\text { Odd ratio }\end{array}$ & \multirow[t]{2}{*}{$\begin{array}{l}\mathrm{P} \text { - } \\
\text { value }\end{array}$} \\
\hline & & $95 \%$ C I & & $95 \%$ C I & \\
\hline \multirow[t]{3}{*}{ Age } & $13-15$ yrs & $\begin{array}{l}3.788(2.802- \\
5.123)\end{array}$ & .000 & $\begin{array}{l}8.570(5.368- \\
13.684)\end{array}$ & 0.000 \\
\hline & $10-12$ yrs & $\begin{array}{l}2.216(1.685- \\
2.914)\end{array}$ & .000 & $\begin{array}{l}1.933(1.180- \\
3.166)\end{array}$ & 0.009 \\
\hline & $5-9$ yrs & 0. & . & 0. & . \\
\hline \multirow[t]{2}{*}{ Sex } & Male & $\begin{array}{l}1.394(1.114- \\
1.743)\end{array}$ & 0.004 & $\begin{array}{l}1.343(0.948- \\
1.902)\end{array}$ & 0.097 \\
\hline & Female & .0 & . & 0. & . \\
\hline \multirow[t]{2}{*}{ Child ordered } & $>3$ & $\begin{array}{l}1.028(0.810- \\
1.304)\end{array}$ & 0.820 & $\begin{array}{l}1.233(0.861- \\
1.767)\end{array}$ & 0.253 \\
\hline & $\leq 3$ & 0 & . & 0. & . \\
\hline \multirow[t]{2}{*}{ Family size } & $>6$ member & $\begin{array}{l}1.257(0.979- \\
1.615)\end{array}$ & 0.073 & $\begin{array}{l}1.157(0.785- \\
1.705)\end{array}$ & 0.461 \\
\hline & $\leq 6$ & 0. & . & 0. & \\
\hline \multirow[t]{2}{*}{ Father education } & $\begin{array}{l}\text { Illiterate/low } \\
\text { level }\end{array}$ & $\begin{array}{l}1.034(0.704- \\
1.519)\end{array}$ & 0.864 & $\begin{array}{l}0.642(0.369- \\
1.116)\end{array}$ & 0.116 \\
\hline & well educated & 0. & . & 0. & . \\
\hline \multirow[t]{2}{*}{ Father occupation } & $\begin{array}{l}\text { Not or daily } \\
\text { worker }\end{array}$ & $\begin{array}{l}1.067(0.827- \\
1.377)\end{array}$ & 0.618 & $\begin{array}{l}0.941(0.643- \\
1.375)\end{array}$ & 0.752 \\
\hline & $\begin{array}{l}\text { employee/ skill } \\
\text { worker }\end{array}$ & 0. & . & $0 .$. & . \\
\hline \multirow[t]{2}{*}{ Mother education } & $\begin{array}{l}\text { illiterate/low } \\
\text { level }\end{array}$ & $\begin{array}{l}1.144(0.699- \\
1.871)\end{array}$ & 0.592 & $\begin{array}{l}1.571(0.692- \\
3.567)\end{array}$ & 0.280 \\
\hline & well educated & 0. & . & 0. & . \\
\hline \multirow[t]{2}{*}{ Mother occupation } & Worker & $\begin{array}{l}1.004(0.611- \\
1.650)\end{array}$ & 0.986 & $\begin{array}{l}1.039(0.483- \\
2.238)\end{array}$ & 0.922 \\
\hline & not worker & .0 & . & 0. & . \\
\hline \multirow[t]{2}{*}{ Locality } & Locality: rural & $\begin{array}{l}2.406(1.768- \\
3.274\end{array}$ & 0.000 & $\begin{array}{l}3.437(2.091- \\
5.649)\end{array}$ & .000 \\
\hline & Urban & 0. & . & 0. & . \\
\hline \multirow[t]{2}{*}{$\begin{array}{l}\text { Source of drinking } \\
\text { water }\end{array}$} & Tanker & $\begin{array}{l}.709(0.521- \\
0.966)\end{array}$ & 0.029 & $\begin{array}{l}0.585(0.367- \\
0.933)\end{array}$ & 0.024 \\
\hline & unprotected & $\begin{array}{l}\text { 1.065(0.664- } \\
\text { Page 8/16 }\end{array}$ & 0.793 & 1.047(0.534- & 0.894 \\
\hline
\end{tabular}




\begin{tabular}{|c|c|c|c|c|c|}
\hline & open well & 1.709) & & 2.054) & \\
\hline & Tap & 0. & . & 0. & . \\
\hline \multirow[t]{3}{*}{$\begin{array}{l}\text { Meal during the day at } \\
\text { school }\end{array}$} & not taken & $\begin{array}{l}1.035(0.747- \\
1.434)\end{array}$ & 0.835 & $\begin{array}{l}1.313(0.817- \\
2.109)\end{array}$ & 0.261 \\
\hline & from house & $\begin{array}{l}1.083(0.850- \\
1.379)\end{array}$ & 0.520 & $\begin{array}{l}0.894(0.608- \\
1.316)\end{array}$ & 0.571 \\
\hline & from school & 0 & . & 0. & . \\
\hline
\end{tabular}

and across the countries example Ethiopia $[11,12,13,14,15]$, Nigeria [16,17,18], Tanzania [19], India [20].

The relatively high prevalence of under-nutrition observed among school children in rural areas of the state may be due to the inadequate quantitative and qualitative dietary food intake. Un- surprising, the state has already a long-suffered poverty and lack of access to the main services including health and education [21] that result in poor school environment and increase the risk of prevalence of infectious diseases. Alongside, the fact that the state practices food insecurity and food taboos, as some type of food, which is rich in animal proteins, was prohibited to women and children [21, 22].

Older children were more likely to be stunted and thinness than the younger age group $[23,24,25,26,27]$. These groups of children are in critical period of physical growth and need special attention to meet the high demand of key nutrient. Failure to consume an adequate diet can result in thinness [28]. Various studies in different countries showed that under-nutrition exists in both sexes and in different age groups $[14,29,30]$. On the other studies; boys were more likely to suffer from under nutrition compared to girls $[11,27,31,32,33]$. This difference can be explained by increasing physical activity habits of boys that require an increased amount of energy and nutrients [34,35]. Deficiency of the requirement will result in poor growth that affects the working capacity. As children growing up, they are expected to work outside the home to support their families. Unsurprising most of the studied children were from low socio economic background, and look for helping their families as this appear in the decreasing number of boys at the high level of schools. Among female the prevalence of overweight was observed [36]. The potential explanation girls spent most of time in the house that give them a greater chance to eat what is available in the house than boys.

Maternal education and occupation had no significant effect on child nutrition status that is in the same way of finding in Ethiopia [13] and unlike the finding of Nabag et al 2011[33] who showed the association of maternal education, family size and child ordered with child nutrition status. Poor education of mothers put them in poor position to make decision of child needs. As in many areas in eastern Sudan, the decision was held by men in the family. Poor nutritional knowledge and education besides food taboos are behind the prevalence of malnutrition [22]. Furthermore, usage of unsafe water, which is significantly associated with the prevalence of malnutrition, may contribute to the prevalence of disease agents that affect the child health and nutrition. So improving of drinking water is important for improving the nutrition status of children as early reported [37]. 


\begin{tabular}{|c|c|c|c|c|c|}
\hline \multirow[t]{2}{*}{ Variable } & \multirow[t]{2}{*}{ Category } & $\begin{array}{l}\text { Over weight/ obese } \\
\text { Odd ratio }\end{array}$ & \multirow[t]{2}{*}{$\begin{array}{l}\mathrm{P}- \\
\text { value }\end{array}$} & $\begin{array}{l}\text { Thinness } \\
\text { Odd ratio }\end{array}$ & \multirow[t]{2}{*}{$\begin{array}{l}\mathrm{P}- \\
\text { value }\end{array}$} \\
\hline & & $95 \%$ C I & & $95 \%$ C I & \\
\hline \multirow[t]{3}{*}{ Age } & $13-15$ yrs & $1.193(0.760-1.872)$ & 0.443 & $\begin{array}{l}1.154(.912- \\
1.459)\end{array}$ & .233 \\
\hline & $10-12$ yrs & $0.985(0.672-1.445)$ & 0.940 & $\begin{array}{l}0.956(.783- \\
1.167)\end{array}$ & .655 \\
\hline & $5-9$ yrs & 0. & $\cdot$ & 0. & \\
\hline \multirow[t]{2}{*}{ Sex } & male & $0.759(0.533-1.081)$ & 0.127 & $\begin{array}{l}1.717(1.436- \\
2.052)\end{array}$ & .000 \\
\hline & Female & 0. & . & 0. & . \\
\hline \multirow[t]{2}{*}{ Child ordered } & $>3$ & $0.753(0.515-1.102)$ & 0.144 & $\begin{array}{l}1.027(.848- \\
1.245)\end{array}$ & 0.782 \\
\hline & $\leq 3$ & 0. & & 0 & $\cdot$ \\
\hline \multirow[t]{2}{*}{ Family size } & $>6$ member & $0.851(0.591-1.228)$ & 0.389 & $\begin{array}{l}0.924(0.760- \\
1.124)\end{array}$ & 0.429 \\
\hline & $\leq 6$ & 0. & . & 0. & . \\
\hline \multirow[t]{2}{*}{ Father education } & $\begin{array}{l}\text { Illiterate/low } \\
\text { level }\end{array}$ & $0.836(0.497-1.405)$ & 0.498 & $\begin{array}{l}0.764(0.569- \\
1.025)\end{array}$ & 0.072 \\
\hline & well educated & 0. & . & 0. & . \\
\hline \multirow[t]{2}{*}{ Father occupation } & $\begin{array}{l}\text { Not or daily } \\
\text { worker }\end{array}$ & $0.739(0.509-1.072)$ & 0.111 & $\begin{array}{l}0.767(0.629- \\
0.936)\end{array}$ & 0.009 \\
\hline & $\begin{array}{l}\text { employee/ skill } \\
\text { worker }\end{array}$ & 0. & . & 0. & . \\
\hline \multirow[t]{2}{*}{ Mother education } & $\begin{array}{l}\text { illiterate/low } \\
\text { level }\end{array}$ & $0.754(0.413-1.374)$ & 0.356 & $\begin{array}{l}1.022(0.710- \\
1.472)\end{array}$ & 0.906 \\
\hline & well educated & 0. & & 0. & \\
\hline \multirow[t]{2}{*}{ Mother occupation } & Worker & $0.978(0.462-2.071)$ & 0.954 & $\begin{array}{l}0.848(0.569- \\
1.265)\end{array}$ & 0.420 \\
\hline & not worker & 0. & . & 0. & . \\
\hline \multirow[t]{2}{*}{ Locality } & Locality: rural & $0.825(0.539-1.264)$ & 0.377 & $\begin{array}{l}1.885(1.487- \\
2.389)\end{array}$ & .000 \\
\hline & urban & 0. & . & 0. & . \\
\hline \multirow[t]{2}{*}{$\begin{array}{l}\text { Source of drinking } \\
\text { water }\end{array}$} & Tanker & $1.003(.643-1.566)$ & 0.988 & $\begin{array}{l}0.865(.677- \\
1.104)\end{array}$ & 0.244 \\
\hline & unprotected & $.890(.342-2.314)$ & 0.810 & $2.205(1.484-$ & .000 \\
\hline
\end{tabular}




\begin{tabular}{|llllll|} 
& \multicolumn{2}{l}{ open well } & & \multicolumn{2}{l|}{$3.276)$} \\
\cline { 2 - 5 } & tap & 0. &. & 0. &. \\
\hline $\begin{array}{l}\text { Meal during the day } \\
\text { at school }\end{array}$ & not taken & $0.811(0.455-1.447)$ & 0.479 & $2.744(2.131-$ & .000 \\
& & & $3.532)$ & \\
\cline { 2 - 5 } & from house & $0.852(0.588-1.234)$ & 0.396 & $1.752(1.441-$ & .000 \\
& from school & 0. & & $0.129)$ \\
\hline
\end{tabular}

\section{Conclusion}

The present study highlighted the prevalence of malnutrition in different forms among school children that will provide a baseline data for school health in the state. More attention is needed from policymakers on nutrition status of this sector by nutrition intervention, promotion of school feeding, improvement of the school environment, maternal education, and regular health assessment.

\section{Abbreviations}

OR: Odd ratio

Cl: Confidence interval

\section{Declarations}

\section{Ethics approval :}

Ethical clearance was obtained from the Health research ethics committee- ministry of health- Kassala state. Communication was through formal official letter to ministry of education that provided an official letters to all selected schools. All the study was conducted in accordance with the Sudan Federal Ministry of Health guidelines.

Consent to participate : Informed verbal consent was obtained from all participant and their care givers, before the interview. The rights of the student not to take part and not to answer the query they do not want to answer were ensured. To ensure the confidentiality of participants, anonymous coding was used.

\section{Consent for publication}

Not applicable

\section{Availability of data and materials}

The datasets used and/or analyzed during the current study are available from the corresponding author on reasonable request. 


\section{Competing interests}

All the authors certify that they have no affiliations with or involvement in any organization or entity with any financial interest or non-financial interest in the subject matter or materials discussed in this manuscript.

\section{Funding}

This project was funded in 2016 from Ministry of Higher Education and Scientific Research Sudan. The funder had no role in study design, data collection and analysis, decision to publish, or preparation of the manuscript

\section{Authors' contributions :}

FAK, MME, MEE and MAE, had contribution on Study design. Data collection: FAK, MEE and MAE . Data management and analysis were performed by FAK and MME. Analyzed data were revised and approved by all the authors. Manuscript was written by FAK and MAD, revised by MMM and approved by all authors.

\section{Acknowledgement}

All authors would like to thank all the study participants, their guardians, data collectors and principals and teachers of the selected schools for their cooperation and their contribution to success this research. Furthermore, our thanks extended to administrative offices of selected localities. Our thanks extended to the funder (Ministry of Higher Education and Scientific Research, Sudan).

\section{References}

[1] Jukes M, McGuire J, Method F, Sternberg R. Nutrition: a foundation for development,Geneva: ACC/SCN, 2002; 1-4. http://www.bvsde.paho.org/texcom/nutricion/intnut2.pdf

[2] WHO: [Global Nutrition Report 2018]4.

[3] UNICEF-Sudan Annual Report 2019

[4] Srivastava A, Mahmood SE, Srivastava PM, Shrotriya VP, Kumar B. Nutritional status of school-age children- A scenario of urban slums in India. Arch public Health. 2012; 70: 8

[5] Olusanya JO. Assessment of the food habits and school feeding programme of pupils in a rural community in Odogbolu local government area of Ogun state, Nigeria. Pak J Nutr 2010; 9:198-204

[6] Zemenu YK, Tsigereda B, Alemu M, Mesfine T, Sintayehu Y, "Malnutrition and associated factors among under five children (6-59 months) at Shashemene referral hospital, West Arsi zone, Oromia, Ethiopia," Current Pediatric Research. 2017; 21(1), 172-180. 
[7] Ministry of Health, 'Sudan National Simple Spatial Surveying (S3M) Method', 2013.

[8] Global nutrition Report 2020. https://globalnutritionreport.org/resources/nutritionprofiles/africa/northern-africa/sudan/.

[9] WHO Multicentre Growth Reference Study Group (2006) WHO Child Growth Standards: Length/heightfor-age, weight-for-age, weight-for-length, weight-for-height and body mass index-for-age: methods and development.

[10] de Onis M, Onyango AW, Borghi E, Siyam A, Nishida C, et al. (2007) Development of a WHO growth reference for school-aged children and adolescents. Bull World Health Organ 85: 660-667.

[11] Mesfin F, Berhane Y and Worku A. School-Aged Children Felling Hunger at School Were at a Higher Risk for Thinness in Kersa District, Eastern Ethiopia: A Cross-Sectional Study. J Nutr Food Sci 2015. S12:005. doi: 10.4172/2155-9600.S12-005

[12] Endris N, Asefa H, Dube L. Prevalence of Malnutrition and Associated Factors among Children in Rural Ethiopia. Biomed Res Int. 2017; 2017: 6587853

[13] Tefera E, Mohammed J, Mitiku H. Nutritional Status of School Children in Babile Town, Eastern Ethiopia . East African Journal of Health and Biomedical Sciences. 2017: 1(2): 1-10

[14] Mitiku H, Admassu D, Teklemariam Z, Weldegebreal F, Nigusse A. Nutritional status of school children in eastern Hararghe administrative zone, eastern Ethiopia. J of Public Health: From Theory to Practice. 2018. https://doi.org/10.1007/s10389-018-0919-3

[15] Tariku EZ, Abebe GA, Melketsedik ZA, Gutema BT. Prevalence and factors associated with stunting and thinness among school-age children in Arba Minch Health and Demographic Surveillance Site, Southern Ethiopia. PLoS ONE. 2-018; 13(11): e0206659. https://doi.org/ 10.1371/journal.pone.0206659

[16] Amuta EU, Houmsou RS. Assessment of Nutritional Status of School Children in Makurdi, Benue State. Pak. J. Nutr.,2009; 8 (5): 691-694.

[17] Senbanjo IO, Oshikoya KA, Odusanya OO, Njokanma OF, "Prevalence of and risk factors for stunting among school children and adolescents in Abeokuta, Southwest Nigeria," Journal of Health, Population and Nutrition. 2011; 29 (4). 364-370.

[18] Eze J N, Oguonu T, Ojinnaka N C, Ibe B C. Physical growth and nutritional status assessment of school children in Enugu, Nigeria. Niger J Clin Pract. 2017; 20: 64-70.

[19] Teblick A, De Deken S, Vanderbruggen W, Vermeersch M, Teblick S, Ruymaekers M, Andries J, Colebunders R, Mmbando BP. Anthropometry and Nutritional Status of Primary School Children in a Suburban Region in Tanzania Int J School Health. 2017; 4(3):e46079. 
[20] Syed S, Rao R. Factors influencing nutritional status of school children in an urban slum of Hyderabad, India. Int J Contemp Pediatr. 2015; 2(4):335-339.

[21] WFP. A Comprehensive Food Security Assessment in Kassala State, Sudan, UN World Food programme, Kassala State Ministry. 2012.

[22] Khalid FA, Ali AKM, Ali SA, Mosmar ZYA, Salih SSM, Salman TK, Desogi MA, Soghaier MA, Mohammed EE, Mohammed AA. Households' dietary habits and food consumption patterns in Hamishkoreib locality, Kassala State, Sudan. J Ethn Foods. 2017; 4, $181 \mathrm{e} 186$

[23] Mulugeta A, Hagos F, Stoecker B, Kruseman G, Linderhof V, Abraha Z, Yohannes M, Samuel GG.Nutritional status of adolescent girls from rural communities of Tigray, northern Ethiopia. Ethiop $J$ Health Dev. 2009; 23(1):5-11

[24] Herrador Z, Sordo L, Gadisa E, Moreno J, Nieto J, Benito A, Aseffa A, Cañavate C, Custodio E. Crosssectional study of malnutrition and associated factors among school aged children in rural and urban settings of Fogera and Libo Kemkem districts, Ethiopia. PLoS One. 2014; 9(9):e105880

[25] Amare B, Moges B, Fantahun B, Tafess K, Woldeyohannes D, Yismaw G, Ayane T, Yabutani T, Mulu A, Ota F, Kassu A. Micronutrient levels and nutritional status of school children living in Northwest Ethiopia. Nutrition Journal. 2012; 11:108

[26] Francis L, Kirunda BE, Orach CG. Intestinal helminth infections and nutritional status of children attending primary schools in Wakiso District, Central Uganda. Int J Environ Res Public Health. 2012; 9:2910-21.

[27] Fazili A, Mir AA, Pandit IM, Bhat IA, Rohul J, Shamila H. Nutritional status of school age children (5-14 years) in a rural health block of North India (Kashmir) using WHO Z-score system. Online J Health Allied Scs. 2012; 11(2):2

[28] Checkley W, Buckley G, Gilman RH, Assis AM, Guerrant RL, et al. Multi-country analysis of the effects of diarrhoea on childhood stunting. Int J Epidemiol. 2008; 37: 816-830.

[29] Mwaniki EW, Makokha AN .Nutrition status and associated factors among children in public primary schools in Dagoretti, Nairobi, Kenya. African Health Sciences 2013; 13:1.

[30]Medhi GK, Barua A, Mahanta J. Growth and nutritional status of school age children (6-14 years) of tea garden worker of Assam. J Hum Ecol. 2006; 19:83-85.

[31] Wamani H, Tylleskär T, Astrøm AN, Tumwine JK, Peterson S. Mothers' education but not fathers' education, household assets or land ownership is the best predictor of child health inequalities in rural Uganda. Int J Equity Health. 2004; 3: 9. 
[32] Kabubo-Mariara J, Ndenge G. "Determinants of Children's Nutritional Status in Kenya: Evidence from Demographic and Health Surveys " Journal of African Economies. 2008; 18: 363-387.

[33] Nabag FO. Comparative Study of Nutritional Status of Urban and Rural School Girl's Children associated factors among school aged children in rural and urban setting of Fogera and Libo districts, Ethiopia. Journal of Science and Technology. 2011; 12:02.

[34] Peltzer K. Leisure time physical activity and sedentary behavior and substance use among in-school adolescents in eight African countries. International Journal of Behavioural Medicine. 2010; 17, 271-278

[35] Mamabolo RL, Kruger HS, Lennox A, Monyeki MA, Pienaar AE, Underhay C, Czlapka-Matyasik M. Habitual physical activity and body composition of black township adolescents residing in the North West Province, South Africa. Public Health Nutrition. 2007; 10: 1047-1056

[36] Manyanga T, El-Sayed H, Doku DT, Randall JR. The prevalence of underweight, overweight, obesity and associated risk factors among school-going adolescents in seven African countries. BMC Public Health. 2014;14:887.

[37] Dearden KA, Schott W, Crookston BT, Humphries DL, PennyE, Behrman JR. Children with access to improved sanitation but not improved water are at lower risk of stunting compared to children without access: a cohort study in Ethiopia, India, Peru, and Vietnam. BMC Public Health. 2017; 17: 110.

\section{Figures}

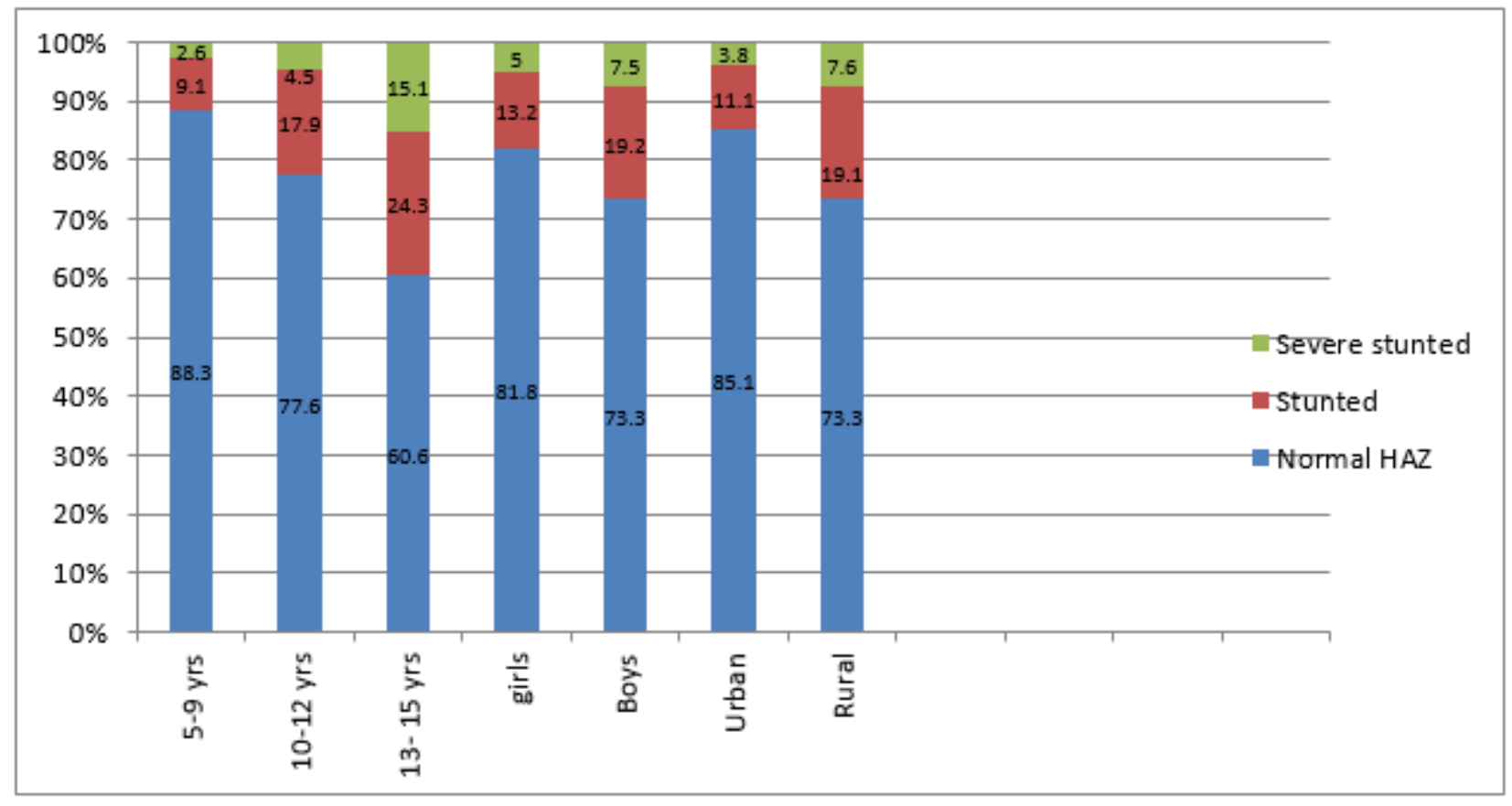

\section{Figure 1}


Proportion of chronic malnutrition (stunting) according to child age, sex and locality

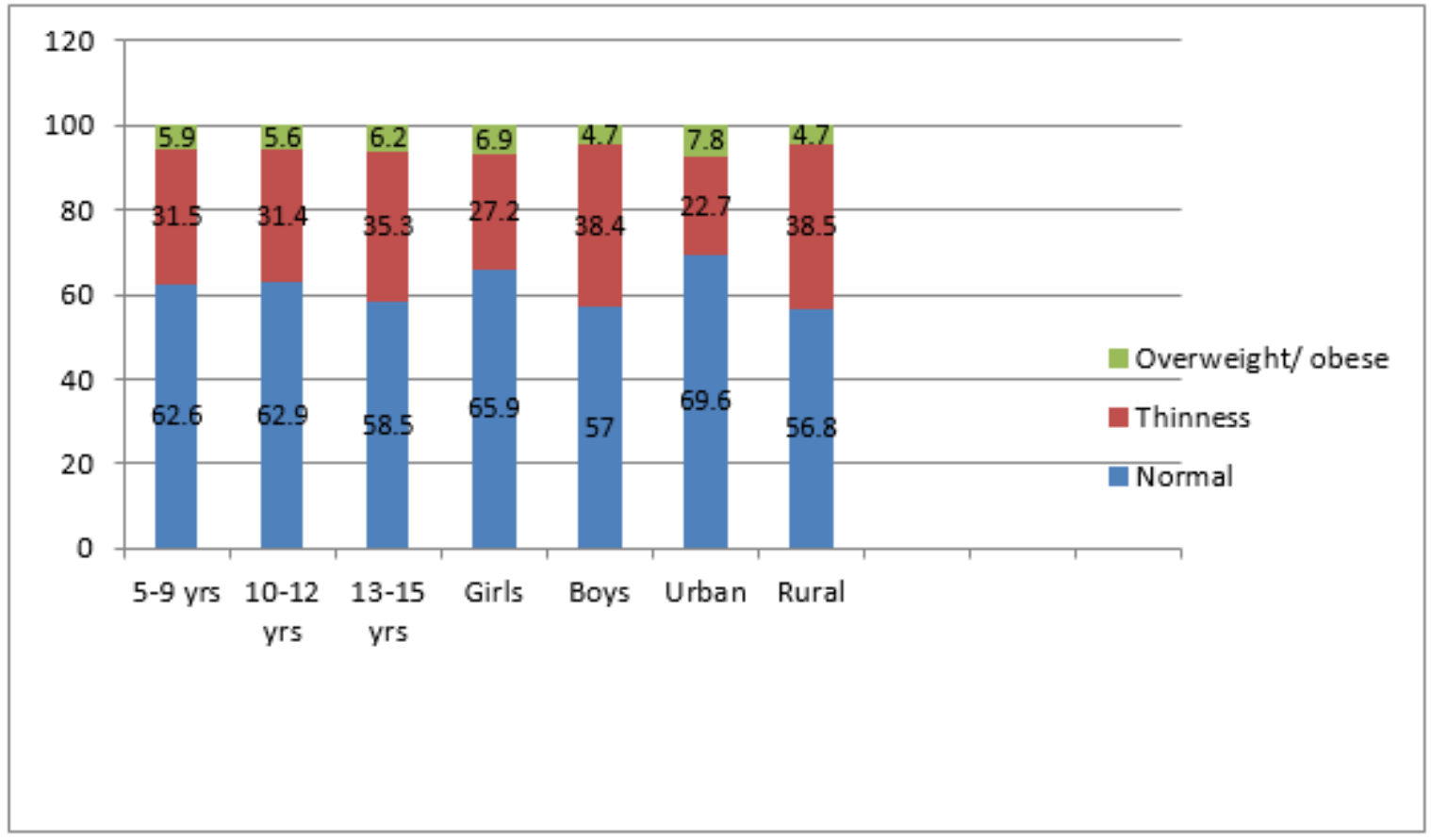

Figure 2

proportion of acute malnutrition (thinness) according to child age, sex and locality 